\title{
MICROSURGERY TRAINING IN FRANCE
}

\section{J. Legagneux}

\author{
Ecole de chirurgie (AGEPS) - AP-HP, Paris, France
}

The Microsurgery began in France in 1972. Since the beginning of many training centers have been created, today we identify 19 places of education throughout the territory. Each training center organizes its own program so we will present here the experience of microsurgery teaching as it is carried out at the $\ll$ Ecole de chirurgie de l'assistance Publique Hôpitaux de Paris». The microsurgery lab has 44 years experience in microsurgery education and the author has helped set up the programs and their organization and she has been involved in education for over 40 years.
Keywords:
Microsurgery, education, France.
Conflict of interest:
the authors declare the absence of obvious and potential conflicts of interest related to the publication of this article.
Financial disclosure: no author has a financial or property interest in any material or method metioned.
For citation:

\section{ОБУЧЕНИЕ МИКРОХИРУРГИИ ВО ФРАНЦИИ}

Ж. Меганье

$$
\text { Школа хирургии (AGEPS) - АР-НР, г. Париж, Франция }
$$

\begin{abstract}
Микрохирургия во Франции появилась в 1972 г. В то время было создано множество учебных центров. Сегодня мы выделяем 19 центров обучения по всей территории страны. КажАый учебный центр имеет собственную программу. В настоящей статье мы преАставим опыт преподавания микрохирургии в Есоlе de

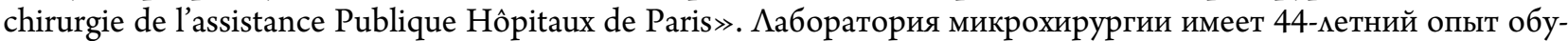
чения в области микрохирургии. Автор принимала участие в созАании программ и их организации, в работе центра она участвует более 40 мет.
\end{abstract}

\begin{abstract}
Ключевые слова: микрохирургия, образование, Франция.
Конфмикт интересов: авторы подтвержАают отсутствие конфликта интересов, о котором необходимо
\end{abstract} сообщить.

Прозрачность финансовой Аеятельности: материалах или методах.

Амя цитирования: $\quad$ Аеганье Ж. Обучение микрохирургии во Франции. Вопросы реконструктивной и пластической хирургии. 2021;24(1):77-80. doi: 10.52581/1814-1471/76/9

\section{HISTORY OF EDUCATION IN MICROSURGERY IN FRANCE}

The Microsurgery began in France date from 1972-1974. In 1976, surgeons from several surgical disciplines decided to share their experiences and develop Microsurgery by creating the Group "GAM" (Group for the Advancement of Microsurgery) whose 1st President was Professor Jacques
Baudet. In 2020, GAM was to organize its 42nd Congress.

The first training in Microsurgery appeared in 1972. Between 1972 and 1983, 11 training centers had been created. Today we have 19 training locations across the whole of France.

Despite some attempts, notably through the GAM, to seek to standardize training at the national level, this has never succeeded and 48 years 
after the opening of the first centers, there is still no standard concerning the organization. formations.

Despite the lack of standardization, there are generally, as at the international level, two levels of training:

- 1 basic course which lasts between 3 and 5 days depending on the centers.

- 1 advanced course lasting between 40 to 120 hours of practical work. Advanced courses are mainly in the form of a University Diploma.

\section{TRAINING PROGRAM IN FRANCE}

\section{The example of the Paris School of Surgery}

The School of Surgery (Fig. 1) has a Microsurgery laboratory specially dedicated to training. This laboratory has been in existence since 1976. There are 11 operating microscopes. At the head of this laboratory have succeeded 3 orthopedic surgeons: Professor A. Gilbert, Professor A.C. Masquelet and now Professor Fr. Fitoussi. Technical supervision is provided by 1 engineer and 2 laboratory technicians.

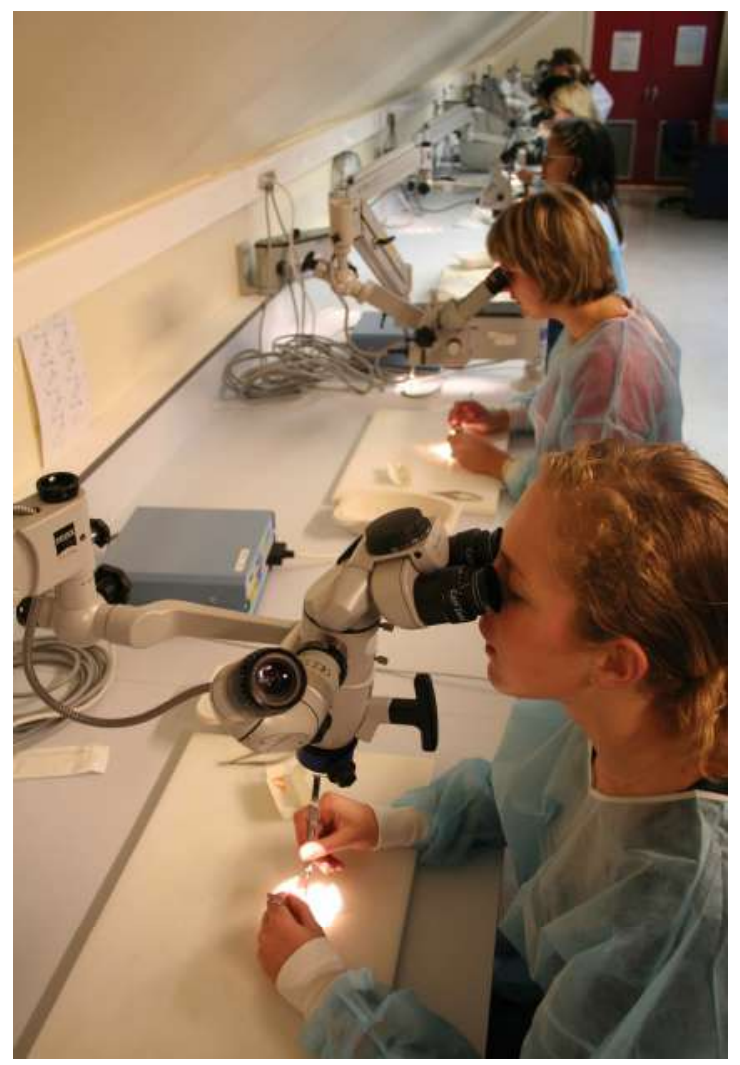

Fig. 1. In the School of Surgery

Рис. 1. В Школе хирургии

We organize 2 courses: a basic course and an advanced course (University Diploma).

The training courses are open to all surgeons of any specialty and of any origin (more than 70 nationalities to date). Since its opening, around 2,450 students have followed the initial training and 1,550 the University Diploma. The trainees are mainly surgical residents from Paris.

Currently, we welcome above 60 people per year for basic training and also above 60 trainees of the University Diploma.

\section{Organization and program of basic course}

The 3-day initiation program for microsurgery is as follows:

- how to use a microscope and the instruments;

- knots on compress and on silicone tube;

- dissection and anastomosis of the rat abdominal aorta;

- dissection and anastomosis of the carotid artery and the external jugular vein;

- dissection and anastomosis of the femoral artery and vein; vein.

- bypass of the aorta through the external jugular

\section{Organization and Program of the University Di- ploma (Fig. 2)}

The practical teaching of the University Diploma takes place over 9 months. Each student comes to train for half a day a week, for a total of 30 four-hour sessions.

Program :

Students have a training about twenty techniques on the rat. Several end to end anastomosis, grafts, bypass, kidney transplantation, groin flap transfer at the opposite side or on the neck.

Our teaching method is the formation by increasing difficulties - during the first 15 sessions the students never do the same technique but they practice techniques which are more and more difficult. We think that it's good method for doing progress.

\section{STEP-BY-STEP TECHNIQUES OF END-TO-END AND END-TO-SIDE ANASTOMOSES}

All anastomoses are performed at separate points and using the symmetrical biangulation technique.

\section{DIFFERENT MODELS USED FOR THE EDUCATION; NON-LIVING AND LIVING}

For the first steps in learning microsurgery, we use compresses to learn how to tie knots and silicone tubes to learn how to make anastomoses. These two exercises are done over a whole day.

Then we offer two practice sessions on the chicken thigh before performing all the other exercises in the anesthetized rat. 
FACULTE DE MEDECINE - SORBONNE UNIVERSTTE

\author{
DIPLOMME UNIVERSITAIRE DE \\ TECHNIQUES MICROCHIRURGICALES \\ Année universitaire 2020 - 2021
}

Directear d'enseignement : Professeur F. FIIOUSSI

L'enseignement comprend 25 heures de cours théoriques ef 120 heures de travaur pratiques.

\title{
PROGRAMMIE DES COURS THEORIQUES
}

\begin{tabular}{|c|c|c|}
\hline $\begin{array}{l}\text { Lasodi } 30 \text { Nevembre } 2020 \\
\qquad \begin{array}{l}14 \mathrm{~h} 00 \\
15 \mathrm{~h} 00 \\
16 \mathrm{~h} 00 \\
17 \mathrm{~h} 00\end{array}\end{array}$ & 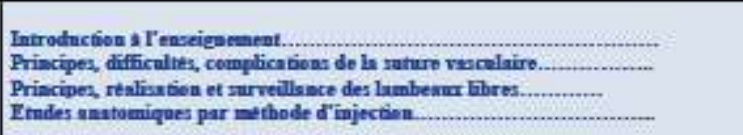 & $\begin{array}{l}\text { F. FTrOUSSI } \\
\text { J. IFGAGNEX, J.I. VIGNES } \\
\text { F. FITOUSSI } \\
\text { L. BOUECHEXX }\end{array}$ \\
\hline $\begin{array}{c}\text { Iandi } 4 \text { ienvier } 2021 \\
14 \mathrm{~h} 00 \\
15 \mathrm{~h} 00 \\
16 \mathrm{~h} 00 \\
13 \mathrm{~h} 00 \\
\end{array}$ & 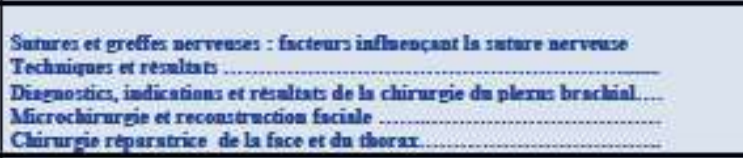 & $\begin{array}{l}\text { M. MERTE } \\
\text { M. MERTE } \\
\text { R. BOSC } \\
\text { L. LANTIERI } \\
\end{array}$ \\
\hline $\begin{array}{l}\text { Inadi } 25 \text { Janvier } 20 \mathrm{~h} \\
14 \mathrm{~h} 00 \\
15 \mathrm{~h} 00 \\
16 \mathrm{~h} 00 \\
17 \mathrm{~h} 00\end{array}$ & 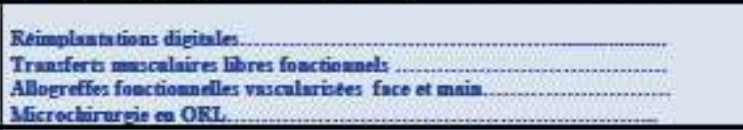 & $\begin{array}{l}\text { P. MASMEJEAN } \\
\text { A. CAMBON-BINDER } \\
\text { L. LANTIEKI } \\
\text { D. SALVAY } \\
\end{array}$ \\
\hline $\begin{array}{l}\text { Fand } 8 \mathrm{Mar} 2021 \\
14 \mathrm{~h} \mathrm{00} \\
15 \mathrm{~h} 00 \\
16 \mathrm{~h} 00 \\
17 \mathrm{~h} 00\end{array}$ & 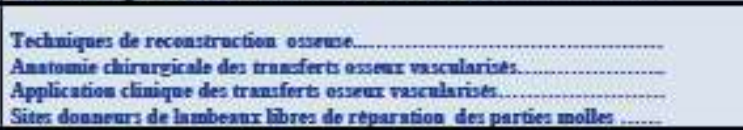 & $\begin{array}{l}\text { F. FTOUSSI } \\
\text { L. BOURCHETX } \\
\text { M. GERMAIN } \\
\text { A.C. MASOUETET }\end{array}$ \\
\hline $\begin{array}{l}\text { Landi } 12 \text { Amin } 2021 \\
14 \mathrm{~h} 00 \\
15 \mathrm{~h} 00 \\
16 \mathrm{~h} \mathrm{00} \\
17 \mathrm{~h} 00\end{array}$ & 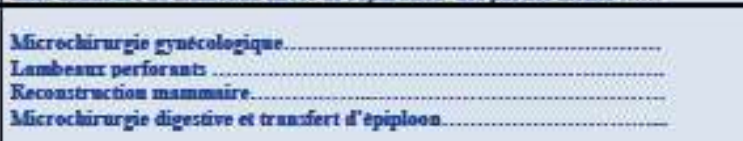 & $\begin{array}{l}\text { M. CARBONTIE } \\
\text { M. ATIAAY } \\
\text { M. ATLAN } \\
\text { M. GERMAIS }\end{array}$ \\
\hline $\begin{array}{l}\text { Landin } 10 \text { mai } 2021 \\
15 \mathrm{~h} 00 \\
16 \mathrm{~h} 00 \\
17 \mathrm{~h} 00\end{array}$ & 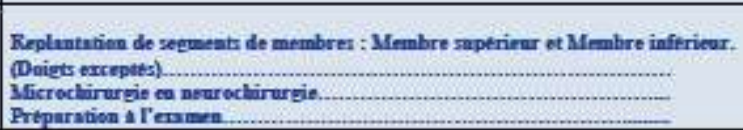 & $\begin{array}{l}\text { I.N. GOUBIFR } \\
\text { F. PROUST } \\
\text { J.L. VIGNES-N. POITEVIN }\end{array}$ \\
\hline
\end{tabular}

TEAVAIX PRATOQIES

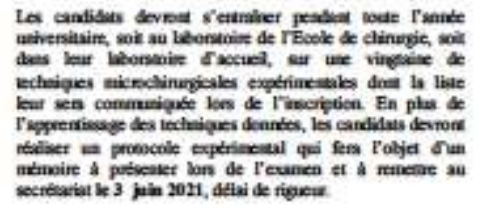
DRROUURENT DE LEXTMEN

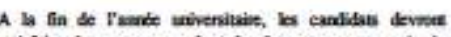

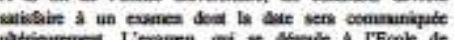

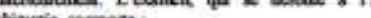
chisares compone:

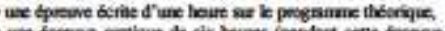

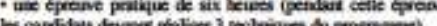

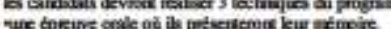

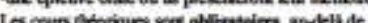

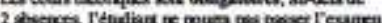

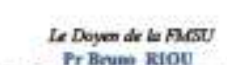$$
\text { Le Dimctear de l'Everigneme }
$$$$
\text { Pr. E. Frrotess }
$$

CONDTMOSS DADMTSSLON

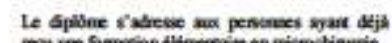

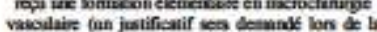
petimscaptom

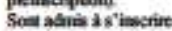

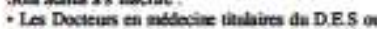

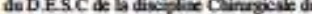

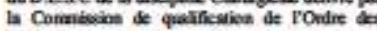
Moblecine.

Les Dockers en ablecin tiakiviet d'ue D.E.S. on du DESC de aptialin chinuberte.

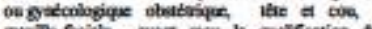

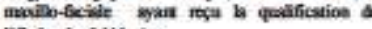
rOide des Maboins

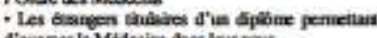
d'eneker lo Medocine dans leur pros.

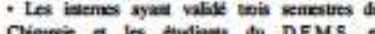

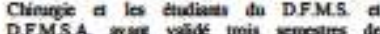

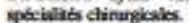

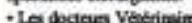

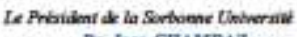

$$
\begin{aligned}
& \text { Pr. Jean CHAMBAZ }
\end{aligned}
$$

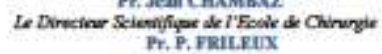

bescurnows

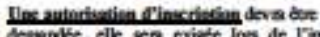

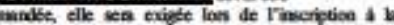

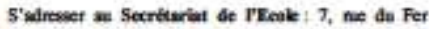

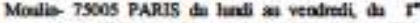

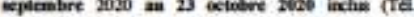
01.466915 .62 ou 15.601

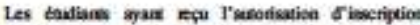

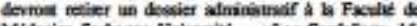

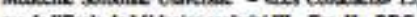

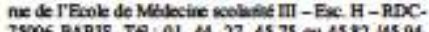

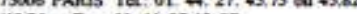

Let inseriptions a lis Factht se fernel din

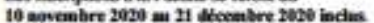

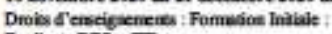
Enularts DES + FF +

CCA iserit en DE.S.C: 1000

F.C. Inilidielle: 20006

FC. Fmployar: 20006

Drobs Ae colariv: $243 \mathrm{f}$

Fig. 2. Organization and Program of the University Diploma

\section{DIFFERENT ASSESSMENTS TOOLS TO DETERMINE QUALITY OF TRAINING}

At the end of each exercise, the trainer checks the quality of the technique and opens the anasto- moses to check the regularity of the passage of the points.

The student also learns to self-criticize, he learns to analyze his mistakes.

In June, at the end of the academic year, students have an exam. This exam consists of a 
theoretical test, and - an oral examination in connection with a small experimental work they made during the year and - the most important part is the practical test - the test is composed of three techniques - Students have to do three techniques in six hours and they must pass two of the three techniques.

\section{MODELS AND CURRICULUM \\ IN SUPER MICROSURGERY, \\ TECHNIQUES IN COMPLETING SUPER MICROANASTOMOSIS}

In the University Diploma program, students perform anastomoses of small diameters (grafting the femoral artery through the epigastric vein for example) but for us "super microsurgery" is a subjective term that has no real meaning. We use a mi- croscope so we do microsurgery, but what does the word "super microsurgery" really mean?

\section{ROBOTIC MICROSURGERY AND ITS TRAINING}

We do not have any experience in robotic microsurgery at the school of surgery. Currently we do not have a robot dedicated to microsurgery, nor an electronic simulator.

\section{FUTURE IN MICROSURGERY EDUCATION; VIRTUAL TRAINING}

In the near future, we plan to reduce the number of exercises using rats and replace them with exercises on inert tissues (chicken thighs for example) in order to respect the $3 \mathrm{R}$ rule. Mental imagery is also a learning support tool that we will develop. A study on the modeling of anastomosis is also underway.

Поступила в редакцию 20.12.2020, утверждена к печати 18.02.2021 Received 20.12.2020, accepted for publication 18.02.2021

\section{Information about the author:}

Josette Legagneux, hospital engineer, microsurgery instructor, Ecole de chirurgie (AGEPS) - AP-HP, Paris, France.

E-mail: josette.legagneux@aphp.fr

\section{Сведения об авторе:}

Жозетт Меганье, госпитальный инженер, инструктор по микрохирургии, Школа хирургии (AGEPS) - AP-HP (г. Париж, Франция).

E-mail: josette.legagneux@aphp.fr 